\title{
APRESENTAÇÃO
}

\section{UNIVERSIDADES E A DITADURA}

\author{
Rodrigo Patto Sá Motta
}

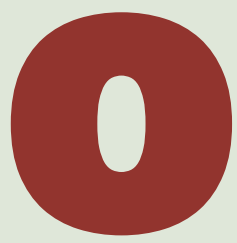

estudo das políticas universitárias da ditadura e do seu impacto nos meios acadêmicos configura tema fundamental para reflexão neste momento em que se completam os 50 anos do golpe de 1964. Nesta direção, deveriam ser considerados, em especial, os resultados alcançados por tais políticas, os estragos provocados pela repressão e as diferentes maneiras como as ações da ditadura foram recebidas pela comunidade universitária. Trata-se de uma questão, ao mesmo tempo, fundamental e polêmica. E plena de atualidade, pois muitas das nossas instituiçōes universitárias foram construídas ou consolidadas durante a ditadura, e, também, porque a parte mais autoritária e elitista desse legado tem sido questionada nos últimos tempos, em que se desenham políticas universitárias mais preocupadas com o desenvolvimento social e o combate às desigualdades.

A pesquisa sobre o período da ditadura ainda é um campo em construção no Brasil, especialmente no concernente à historiografia. Há muitos acervos documentais para explorar, além de testemunhos a serem coletados, e é crescente o número de trabalhos de pós-graduação que vêm se dedicando ao tema. Entretanto, trata-se de campo de pesquisa em consolidação, e ainda há muito a fazer na direção de um conhecimento aprofundado sobre a ditadura. Tal observação geral é particularmente adequada para descrever o caso das universidades, objeto de estudo ainda pouco explorado. Neste dossiê, reunimos contribuições de alguns destacados pesquisadores com trabalhos sobre o tema. São abordagens que apontam a violência política e a repressão dirigida contra os profissionais acadêmicos, mas, também, a existência de espaços de acomodação com a ditadura, bem como os investimentos modernizadores do Estado autoritário.

Rodrigo Patto Sá Motta é professor do Departamento de História da Universidade Federal de Minas Gerais (UFMG), coordenador do grupo de pesquisa "História Política - Culturas Politicas na História" e pesquisador do CNPq e da Fapemig. 